\title{
Paula Gorszczyńska
}

Uniwersytet Gdański

paula.gorszczynska@ug.edu.pl

\section{EMOCJONALNA AUDIODESKRYPCJA}

DOI: http://dx.doi.org/10.12775/RP.2020.008

Zarys treści: Artykuł stanowi podsumowanie komponentu badawczego programu, w ramach którego zrealizowano pokazy filmowe z audiodeskrypcją stworzoną przez studentów Uniwersytetu Gdańskiego. W oparciu o kwestionariusz zbadano preferencje widzących odbiorców audiodeskrypcji w zakresie opisu emocji postaci jednego z odcinków brytyjskiego serialu obyczajowego True Love. Przeanalizowano zgodność interpretacji tych emocji z odczuciami deskryptorów wyrażonymi w scenariuszu AD. Podjęto próbę prześledzenia możliwego wpływu współczesnych koncepcji audiodeskrypcyjnych na wybory dokonane przez autorów badanej ścieżki AD. Zaproponowano także kierunki i metody dalszych badań nad przedmiotowymi zagadnieniami.

Słowa kluczowe: audiodeskrypcja, emocje w AD, współczesne koncepcje audiodeskrypcyjne, preferencje odbiorców AD, klasyfikacja emocji Golemana, analiza semantyczna

\section{Wstęp}

ęzyk emocji towarzyszy człowiekowi na co dzień. Stanowi również nieodzowną część języka audiodeskrypcji (AD) filmowej. I choć wykorzystywane przez tę ostatnią środki językowe mają służyć opisowi treści wizualnych (Chmiel, Mazur 2014: 19), przy opisie emocji zadanie deskryptora zdaje się wykraczać poza ramy oddania tego, co widoczne. Ewoluujące w czasie koncepcje audiodeskrypcji dają mu do tego coraz większe prawo.

Zasadniczą funkcją audiodeskrypcji jest wspomaganie odbioru wytworów kultury przez osoby z różnym stopniem dysfunkcji wzroku lub umożliwianie go tym, których dysfunkcja całkowicie pozbawia ich możliwości 
percepcji wspomnianych wytworów bez takiego opisu słownego ${ }^{1}$. Audiodeskrypcję można klasyfikować różnorako, uwypuklając cechy bądź wskazujące na jej związki z wybranymi działami językoznawstwa ${ }^{2}$, bądź podkreślające medium, którego dotyczy (między innymi film, teatr, sztuki plastyczne, architektura), bądź też plasujące ją na skali od opisu najbardziej obiektywnego do najbardziej subiektywnego. Należy przy tym zaznaczyć, że te dwie ostatnie kategorie częściowo się pokrywają.

Pierwsze wytyczne do opisu obrazu pomiędzy kwestiami dialogów postaci danego materiału filmowego zalecały wysoki stopień obiektywności twórcy ścieżki audiodeskrypcyjnej, neutralność języka opisu i brak terminologii specjalistycznej, co zbliżało charakter opisu do reportażu ${ }^{3}$. Realizacje spełniające te kryteria przez wiele lat uchodziły za przykłady audiodeskrypcji standardowej. Za odchylenie od tak rozumianego standardu w kierunku opisu bardziej subiektywnego można uznać audiodeskrypcję strukturalną. Daje ona priorytet narracji i dopuszcza interpretację, jednak tylko w przypadku, gdy jest ona uzasadniona względami narracyjnymi (Remael, Vercauteren 2007: 73-94). Jeszcze bardziej eksperymentalna wydaje się audiodeskrypcja odzwierciedlająca język filmu (ang. cinematic AD) (Fryer, Freeman 2013: 1-15), która, także dając pierwszeństwo kryterium narracyjności, nie ucieka od terminologii specjalistycznej. Audiodeksrypcja kreatywna (Walczak, Fryer

${ }^{1}$ Ciekawy wgląd w szeroki zakres rozwiązań prawnych, zaleceń technicznych i praktyk AD stosowanych w pięciu państwach europejskich przedstawia Pilar Orero (2007: 111-125).

${ }^{2}$ Badacze audiodeskrypcji powołują się przy tym na Jakobsonowskie kodowanie znaków językowych i pozajęzykowych (Jakobson 2009: 43-45), podkreślając intersemiotyczny charakter audiodeskrypcji ze względu na przekład obrazu na słowo (por. m.in.: Chmiel, Mazur 2011: 15, Bolińska 2014: 169-170). Podejście multisemiotyczne wykorzystano także do analizy korpusowej scenariuszy audiodeskrypcyjnych do filmów w czterech językach w ramach projektu, który zaowocował stworzeniem oprogramowania analizującego narrację, obraz i gramatykę takich skryptów (Jiménez, Seibel 2012: 409-425). W ujęciu przekładoznawczym, w którym AD stanowi jeden z rodzajów tłumaczenia audiowizualnego (Tryuk 2008: 34-35), podkreśla się jej diasemiotyczność, czyli realizację przy udziale dwóch kanałów - wizualnego i werbalnego (Szarkowska 2009: 11). Przekładoznawczy rys audiodeskrypcji wybrzmiewa także między innymi u Mazur (2014: 179-198), ze szczególnym uwzględnieniem strategii pomocnych w przekładzie gestów i wyrazu twarzy z języka obrazu na język słów.

${ }^{3}$ Wytyczne Independent Television Commission (ITC 2000) do dziś stanowią punkt odniesienia dla autorów wskazówek audiodeskrypcyjnych w różnych państwach (por. np. Szymańska, Strzymiński 2010, Orero-Clavero 2012). Bardziej współczesne standardy poluzowują gorset ograniczeń, umożliwiając deskryptorom stosowanie przymiotników oceniających na przykład urodę postaci. Dopuszczalne jest także interpretowanie ich ruchów. Utrzymano zalecenie obiektywności przy opisie emocji za pomocą przysłówków (Ofcom 2017: 22-23). 
2017: 6-17) to kolejny krok w stronę większej swobody interpretacyjnej oryginału poczyniony przy użyciu subiektywnych opisów postaci, zdarzeń i scen oraz terminologii filmowej. W audiodeskrypcji autorskiej (Szarkowska, Wasylczyk 2014: 48-62) znajdziemy opisy subiektywne, emocjonalne, nacechowane, imitujące idiolekt autora, interpretujące i, w miarę możliwości, czerpiące wprost z treści scenariusza. Najdalej od założeń audiodeskrypcji standardowej zdaje się plasować audionarracja, która opiera się na subiektywnej, interpretującej narracji wszechwiedzącego narratora i koncentruje się na opisie stanu emocjonalnego postaci.

Wydaje się, że odbiorcy AD, zwłaszcza ci stanowiący główną grupę docelową, czyli osoby z dysfunkcjami wzroku, nie sprzeciwiają się praktyce nazywania emocji zastępującej lakoniczny opis wyrazu twarzy postaci. To założenie potwierdzają ich opinie zebrane $\mathrm{w}$ toku programu obejmującego serię siedmiu pokazów materiałów filmowych ze ścieżkami AD autorstwa studentów translatoryki anglistycznej na Uniwersytecie Gdańskim4 . Jeden z projektów, które złożyły się na program, został wzbogacony o komponent badawczy. Kolejne części artykułu stanowią rezultat tego komponentu, będący raportem $\mathrm{z}$ badania przeprowadzonego jesienią $2019 \mathrm{r}$.

\section{Badanie}

\subsection{Cel badania}

Nadrzędnym celem badania było poznanie preferencji odbiorców niemających doświadczenia w odbiorze ani tworzeniu audiodeskrypcji w zakresie swobody interpretacyjnej $\mathrm{AD}$ wobec materiału filmowego nacechowanego emocjonalnie. Innymi słowy, starano się ustalić granice tolerancji dla opisu subiektywnego, oferującego eksplicytne nazwy emocji, a także zbadać stopień zgodności odczuć przedstawicieli zwartej społeczności respondentów wyrażonej w ich samodzielnej ocenie emocji postaci oraz w uszeregowanej przez nich hierarchii ważności czynników wpływających na ocenę emocji postaci w materiale filmowym.

${ }^{4}$ Szczegółowe przedstawienie założeń programu oraz jego realizacji w formule zarządzania projektami tłumaczeniowymi przedstawiono w odrębnych publikacjach (Gorszczyńska 2016a, 2016b, Gorszczyńska, Jendza 2016, Gorszczyńska (w druku)). 


\subsection{Uczestnicy badania}

W badaniu wzięło udział 25 studentów pierwszego roku studiów magisterskich w zakresie filologii angielskiej ze specjalności translatorycznej w wieku od 21 do 24 lat, w tym 16 kobiet i 9 mężczyzn. Respondenci nie mieli wcześniejszych doświadczeń ani z tworzeniem, ani z odbiorem materiałów opatrzonych opisem AD.

\subsection{Materiały}

Przedmiotem badania było dziewięć scen (dwanaście sytuacji) wybranych z odcinka brytyjskiego serialu obyczajowego True Love produkcji BBC. Analizowany odcinek przestawia perypetie kobiety $\mathrm{w}$ średnim wieku przeżywającej rozstanie z córką, która wyjechała na studia, jej trudną relację z mężem oraz znajomość z nowo poznanym mężczyzną. Materiał obfituje w emocje postaci wyrażane głównie pozawerbalnie, za pomocą prozodii lub mowy ciała. Nie bez znaczenia dla ich interpretacji, poza fabułą, pozostaje także brzmienie ścieżki dźwiękowej i dialogów, niebędące jednak przedmiotem analiz. Badanie miało charakter kwestionariuszowy.

\subsection{Metoda}

Uczestnikom przedstawiono ustne wprowadzenie do fabuły, po którym, scena po scenie, pokazano im materiał audiowizualny w oryginalnej wersji językowej, bez dodatkowego opisu AD. Po obejrzeniu każdej sceny respondenci mieli nazwać emocję wyrażoną przez wskazaną postać lub dwie postaci i określić jej intensywność w skali od 1 do 5 , gdzie 1 oznacza intensywność najmniejszą, a 5 największą. W tej części badani odpowiadali zatem na jedno lub dwa pytania w odniesieniu do każdej z dziewięciu scen. W drugiej części obejrzeli te same sceny, lecz w polskim tłumaczeniu i wzbogacone o audiodeskrypcję przygotowaną przez studentów z innego rocznika, którzy ukończyli kurs audiodeskrypcji. Tym razem ich zadaniem była ocena trafności opisu $\mathrm{AD}$ w poszczególnych scenach, przy uwzględnieniu ograniczeń czasowych obciążających deskryptora, w oparciu o następującą skalę: 1 - opis bardzo trafny, 2 - opis raczej trafny, 3 - nie mam zdania, 4 - opis raczej nietrafny, 5 - opis zdecydowanie nietrafny. Każdej ze scen należało przypisać po jednej ocenie. Wartościom liczbowym mogły towarzyszyć komentarze uzasadniające zaproponowaną ocenę. 
W odrębnym pytaniu badani mieli uszeregować czynniki mogące wpływać na percepcję emocji postaci w oglądanym materiale od najistotniejszych do najmniej istotnych, uwzględniając następujące aspekty: ścieżkę dźwiękową, tekst dialogu, atmosferę dialogu, kontekst fabuły, scenerię, mowę ciała postaci, ich wyraz twarzy i sposób odczytania kwestii przez lektora.

\subsection{Wyniki}

Stanąwszy przed zadaniem malejącego uszeregowania według ważności wskazanych czynników mogących wpływać na percepcję emocji postaci w materiale audiowizualnym, respondenci średnio przypisali najwyższą wagę (średnia liniowa 163 punkty) wyrazowi twarzy postaci. Na drugim miejscu wskazali ścieżkę dźwiękową i mowę ciała (136 punktów), przy czym przy zastosowaniu wyliczenia na postawie średniej wykładniczej na drugiej pozycji znalazłaby się ścieżka dźwiękowa, na trzeciej fabuła, zaś mowa ciała dopiero na czwartej. Kolejne miejsca, według średniej liniowej, przypadły odpowiednio atmosferze dialogu, fabule, tekstowi dialogu, scenerii i sposobowi odczytywania kwestii przez lektora, przy czym trzy ostatnie nie odbiegają tu od tych odnotowanych według średniej wykładniczej.

Wskazanie wyrazu twarzy postaci jako najistotniejszego nośnika jej emocji zdaje się korespondować $\mathrm{z}$ wysoką, trzecią, pozycją tego czynnika $\mathrm{w}$ towarzyszących ocenie audiodeskrypcji komentarzach do badanego materiału, które przedstawiono w dalszej części artykułu.

Najwięcej ocen pozytywnych (patrz rys. 1) przyznano audiodeskrypcji w ostatniej z badanych scen (39 punktów ${ }^{5}$; brak komentarzy; dominująca ocena natężenia emocji postaci: 4 (52\% respondentów)), przedstawiającej postać głównej bohaterki, Sandry, samotnie jadącej pociągiem, w zbliżeniu na jej twarz. Natomiast najwięcej ocen negatywnych uzyskał opis sceny drugiej (82 punkty; 16 negatywnych komentarzy; ocena natężenia emocji: 3 (40\%), $4(24 \%), 5(16 \%))$, w której także oglądamy Sandrę, tym razem stojącą w witrynie swojego sklepu, wpatrzoną $\mathrm{w}$ niebo. Wydaje się, że pozytywnie oceniona została propozycja AD dotycząca sceny, w przypadku której znaczący procent grupy respondentów (nieco ponad połowa) podzielił opinię co do intensywności dominującej w niej emocji. Z drugiej strony, tam, gdzie wystąpiło widoczne rozstrzelenie wyników oceny intensywności emocji postaci, audiodeskrypcję oceniono w sposób wyraźnie bardziej krytyczny. Tę ostatnią

${ }_{5}$ W tym wypadku im niższa wartość liczbowa, tym korzystniejsza ocena produktu AD. 
obserwację potwierdza także odzwierciedlony w ocenach respondentów odbiór sceny czwartej (Sandra w restauracji z mężem podczas rozmowy o kryzysie ich związku) i szóstej (odmieniona Sandra przed lustrem szykująca się do wyjścia). Także w przypadku tych scen duża grupa respondentów wykazała zgodność opinii o intensywności emocji postaci, bowiem $48 \%$ osób w pierwszym, a 52\% w drugim przypadku oceniło emocję odpowiednio jako intensywną i bardzo intensywną.

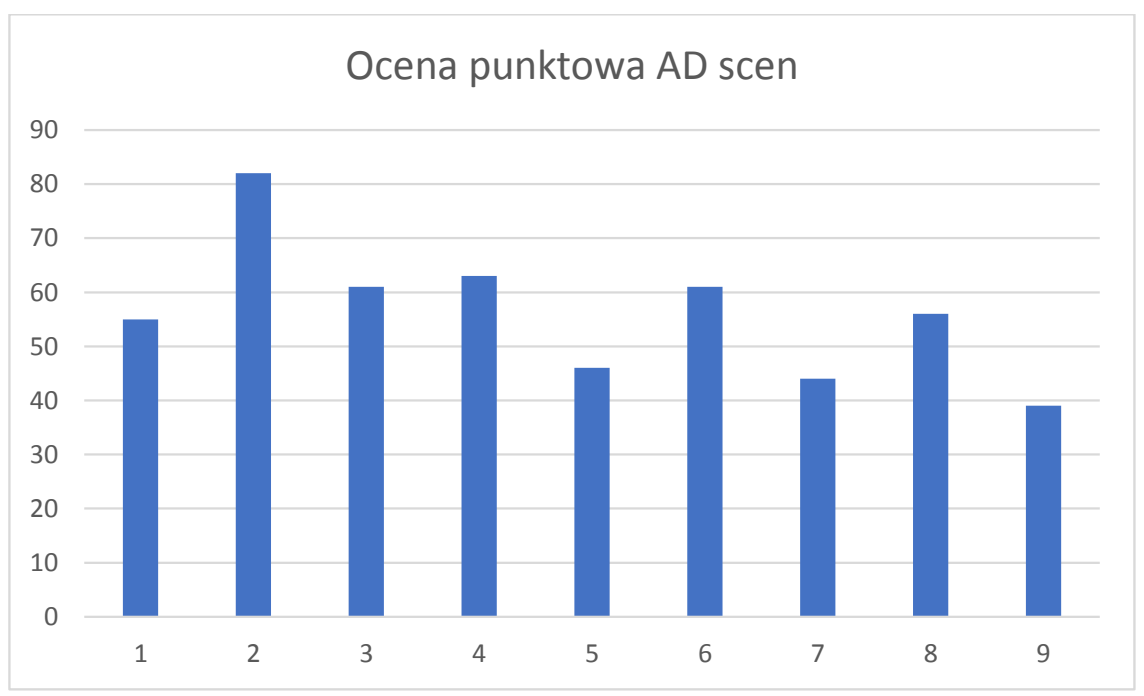

Rys. 1. Wykres oceny punktowej badanych $\operatorname{scen}^{6}$ (opracowanie własne)

By zyskać wgląd w naturę zależności pomiędzy jednoznacznością oceny intensywności emocji a oceną $\mathrm{AD}$ w omawianym badaniu, zasadne wydaje się zestawienie danych o ocenie AD z tymi, które pokazują, jak sami respondenci nazwali emocje dominujące w poszczególnych scenach. Przyjmuje się przy tym, że nie w każdym przypadku wybory nazw emocji dokonane przez respondentów $\mathrm{w}$ pierwszej fazie badania musiały w sposób przewidywalny wpłynąć na ich percepcję trafności $\mathrm{AD}$. To zastrzeżenie wynika $\mathrm{z}$ towarzyszącej badaniu obserwacji, z jaką trudnością przychodziło części badanych nie tyle sklasyfikowanie danej emocji, ile nadanie jej polskiego odpowiednika

${ }^{6} \mathrm{Na}$ osi odciętych oznaczono numery scen, zaś oś rzędnych odzwierciedla punktację przyznaną przez respondentów za opis $\mathrm{AD}$; im niższa wartość liczbowa, tym lepsza ocena. 
nazwy, która bardziej automatycznie przychodziła im do głowy jako pierwsza w języku angielskim. Można założyć, że takie osoby okażą się mniej krytycznie w ocenie niż te, którym nazwanie emocji w języku polskim nie nastręczało problemów.

Aspekt samego mechanizmu rozpoznania danej emocji oraz późniejszego procesu jej nazywania, nieprzewidziany w projekcie badania, wykracza jednak poza ramy niniejszego raportu, co można uznać za jego ograniczenie. W przyszłych pracach tych zagadnień wartościowe mogłoby się okazać wsparcie badania kwestionariuszowego metodami okulograficznymi (Chmiel, Mazur 2011) i neuroobrazowymi (Brooks i in. 2017). Te pierwsze pozwoliłyby na obserwację ruchu gałek ocznych respondentów, wskazując na elementy obrazu, które w największym stopniu przykuły uwagę widzów. Te drugie uzupełniłyby dane badacza o wiedzę na temat rzeczywistego wpływu konkretnych jednostek semantycznych występujących w ścieżce dialogowej lub scenariuszu AD na aktywację obszarów w mózgu odpowiadających za przetwarzanie takich bodźców ${ }^{7}$. Łatwiej dostępną metodą wspomagającą, także stosowaną przez badaczy odbioru AD, jest pomiar tętna badanych po ekspozycji na dany materiał audio lub audiowizualny (Ramos Caro 2015).

W zakresie badania mieści się natomiast analiza produktu, tak w postaci tekstu AD, jak i wyborów leksykalnych dokonanych przez respondentów poproszonych o nazwanie emocji dominującej w danej scenie. W poniższych akapitach zostanie podjęta próba określenia preferencji widzących odbiorców badanego materiału audiowizualnego w oparciu o informacje płynące z obu tych produktów. Tak zarysowana analiza obejmie dwie wspomniane sceny skrajne pod względem punktacji za jakość AD. Jej dopełnieniem będzie przegląd komentarzy respondentów dotyczących także pozostałych scen.

${ }^{7}$ Nie ma przy tym jasności co do wyników badań z zastosowaniem funkcjonalnego rezonansu magnetycznego (fMRI) w zakresie ustalenia, które obszary mózgu odpowiadają za analizę semantyczną. Aktywacja obszarów uznawanych za odpowiedzialne za takie przetwarzanie może bowiem wynikać nie tyle z samego zastosowania danego słowa, ile $\mathrm{z}$ trudności zadania, czyli, w wypadku słów, stopnia ich wyobrażalności. Słowo niestanowiące wyzwania dla mózgu z większym prawdopodobieństwem zostanie bez trudu zmapowane na sieć aktywności bazowej (w stanie relaksu) aniżeli wyraźnie aktywuje tę związaną z wykonywaniem angażującego zadania (Marzec-Remiszewski 2017). Przypuszczalnie w przypadku słów opisujących emocje, czyli byty abstrakcyjne, kryterium przesądzającym o takim potencjale aktywacyjnym mogłyby być natężenie konotacji wywoływanych przez dane słowo utartych w społeczności bądź indywidualnych. 
Tabela 1. Przykładowa ocena scen przez respondentów (opracowanie własne)

\begin{tabular}{|c|c|c|c|c|c|}
\hline $\begin{array}{l}\text { Numer } \\
\text { sceny }\end{array}$ & Opis sceny & $\mathrm{AD}$ & $\begin{array}{c}\text { Dominująca } \\
\text { emocja (liczba } \\
\text { wskazań) }\end{array}$ & $\begin{array}{c}\text { Lączna } \\
\text { ocena } \\
\text { AD } \\
\text { (pkt) }\end{array}$ & $\begin{array}{c}\text { Niedostatki } \\
\text { AD wskazane } \\
\text { w komentarzach }\end{array}$ \\
\hline II & $\begin{array}{l}\text { Niebo. Na } \\
\text { nim wolno } \\
\text { płynące białe } \\
\text { chmury. Sandra } \\
\text { stoi w oknie. } \\
\text { W bezruchu } \\
\text { patrzy w górę } \\
\text { przez okno. } \\
\text { Usta zaciśnięte } \\
\text { w podkowę. } \\
\text { Wreszcie } \\
\text { powoli zamy- } \\
\text { ka... i otwiera } \\
\text { powieki. } \\
\text { Mruga. Widok } \\
\text { z zewnątrz na } \\
\text { sklep z bibelo- } \\
\text { tami. W nim } \\
\text { Sandra w tej } \\
\text { samej pozycji. }\end{array}$ & $\begin{array}{l}\text { Ujęcie na } \\
\text { błękitne niebo. } \\
\text { Obraz płynnie } \\
\text { przechodzi } \\
\text { w twarz } \\
\text { Sandry. Widok } \\
\text { na sklep z bi- } \\
\text { żuterią. }\end{array}$ & $\begin{array}{l}\text { smutek (5) } \\
\text { tęsknota (5) } \\
\text { melancholia (2) } \\
\text { zamyślenie (2) } \\
\text { zaduma (2) } \\
\text { rozdarcie (2) } \\
\text { zrezygnowanie } \\
(2) \\
\text { zagubienie (2) } \\
\text { nostalgia (2) } \\
\text { rozmarzenie (1) } \\
\text { trwoga (1) } \\
\text { zniechęcenie } \\
(1)\end{array}$ & 82 & $\begin{array}{l}\text { - brak opisu } \\
\text { emocji Sandry, } \\
\text { - brak wskazania } \\
\text { na długi czas } \\
\text { trwania spojrze- } \\
\text { nia, } \\
\text { - brak wskazania } \\
\text { na obecność } \\
\text { Sandry w sklepie } \\
\text { i faktu, że wpa- } \\
\text { truje się w okno, } \\
\text { - brak opisu } \\
\text { wyrazu twarzy } \\
\text { Sandry, } \\
\text { - „zbędne obraz } \\
\text { przechodzi w”, } \\
\text { - „[obraz] nie } \\
\text { przechodzi } \\
\text { płynnie, brak } \\
\text { zaznaczenia, } \\
\text { że obrazy są na } \\
\text { siebie nałożone” }\end{array}$ \\
\hline IX & $\begin{array}{l}\text { Torba podróż- } \\
\text { na na fotelu } \\
\text { w wagonie } \\
\text { kolejowym. } \\
\text { Naprzeciw } \\
\text { siedzi Sandra. } \\
\text { Wygląda przez } \\
\text { okno. Twarz } \\
\text { zrelaksowana, } \\
\text { lekko uśmiech- } \\
\text { nięta. }\end{array}$ & $\begin{array}{l}\text { Pociąg. Za } \\
\text { oknem roz- } \\
\text { mazane domy } \\
\text { i drzewa. } \\
\text { Na siedzeniu } \\
\text { podręczna tor- } \\
\text { ba podróżna. } \\
\text { Naprzeciwko } \\
\text { Sandra. Jest } \\
\text { sama. Patrzy } \\
\text { w okno. } \\
\text { Zbliżenie na } \\
\text { jej twarz. Lek- } \\
\text { ki uśmiech. } \\
\text { Obraz zamar- } \\
\text { za. Na dole } \\
\text { pojawiają się } \\
\text { napisy koń- } \\
\text { cowe. }\end{array}$ & \begin{tabular}{|l} 
nadzieja (9) \\
(samo)zadowo- \\
lenie (7) \\
satysfakcja (3) \\
szczéście (2) \\
podekscytowa- \\
nie (1) \\
radość (1) \\
ulga (1) \\
optymizm (1)
\end{tabular} & 39 & brak \\
\hline
\end{tabular}


W przypadku sceny II, określając emocję dominującą w scenie, respondenci posłużyli się aż 12 różnymi leksemami ${ }^{8}$, które, podążając za propozycją klasyfikacji emocji Daniela Golemana9 (1997: 257), można przypisać do dwóch głównych i jednej pobocznej kategorii emocji. Ta mniej znacząca kategoria, bo reprezentowana tu przez zaledwie jeden leksem, wykracza poza klasyfikację Golemana. Na potrzeby tego artykułu przyjęto, że jest kategorią zbiorczą, obejmującą różne emocje pozytywne, niemieszczące się w kategoriach ZADOWOLENIE i MiŁość. Na tle pozostałych kategorii, SMUTEK (84\% wskazanych leksemów) i sTRACH (12\% wskazanych leksemów), jej przedstawiciel, leksem rozmarzenie, wydaje się wynikiem błędnej interpretacji emocji w scenie. W przypadku sceny IX respondenci opisali dominującą emocję, posługując się 8 leksemami z dwóch blisko spokrewnionych kategorii emocji, POZYTYWNE RÓŻNE oraZ ZADOWOLENIE, prZy czym aż 36\% badanych określiło ją zgodnie mianem nadziei, a $28 \%$ jako zadowolenie lub samozadowolenie. Ocenę sceny IX cechuje wysoki poziom zgodności i brak komentarzy wskazujących na niedociągnięcia AD. W przeciwieństwie do komentarzy do sceny II, gdzie zdaniem respondentów zabrakło nie tylko opisu wyrazu twarzy, lecz także opisu emocji, tu nie pojawiły się uwagi wskazujące na potrzebę doprecyzowania opisu w żadnym zakresie, a więc także w odniesieniu do emocji postaci, wyrażonej jedynie opisem jej wyrazu twarzy („lekki uśmiech”).

Oczekiwanie, że AD powinna zapewniać opis twarzy postaci oraz jej emocji, znajduje odzwierciedlenie także $\mathrm{w}$ ocenach pozostałych scen wykorzystanych w badaniu. Wyjściowy studencki scenariusz AD wykorzystany $\mathrm{w}$ poszczególnych scenach przytoczony został poniżej $\mathrm{w}$ punktach oznaczonych przypisanymi do nich cyframi rzymskimi. Na przykład audiodeskrypcję sceny VII opatrzono komentarzami wyraźnie potwierdzającymi oczekiwanie precyzyjnego opisu, także w zakresie emocji („powinien zostać oddany nastrój”, „rozczarowanie w posturze nieuwzględnione”, „nie wspomniano, że wychodzą i o kolejności”, „brak opisu ubioru Sandry”, „nieści-

${ }^{8}$ Najczęściej proponowanymi leksemami oznaczającymi nazwy emocji spośród 110 użytych przez respondentów do samodzielnej oceny emocji bohaterów były: smutek (19\%), rozczarowanie (14,5\%), zadowolenie (14,5\%) i nadzieja (13,6\%). O ile smutek i zadowolenie są zaliczane do emocji podstawowych, dwóch pozostałych nie znajdziemy w klasyfikacji Golemana (1997: 257). Są to jednak jednostki leksykalne stosowane powszechnie.

9 Wskazując trudności badaczy z określeniem, które emocje zasługują na miano podstawowych, Goleman przytacza listę „najczęściej zgłaszanych kandydatów i niektórych członków ich rodzin", czym, jak i dalszym opisem przypadków współwystępowania różnych emocji, podkreśla umowność i niepełny charakter proponowanej klasyfikacji. Emocje podstawowe klasyfikuje w podziale na osiem kategorii: ZŁość, SMUTEK, STRACH, ZADOWOLENIE, MIŁOŚĆ, ZDZIWIENIE, WSTRĘT i WSTYD (Goleman 1997: 257-258). 
słość w opisie”, „niedokładnie”). Podobne uwagi towarzyszą audiodeskrypcji sceny VI i VIII.

(I) Sandra wpatruje się w stół zmartwiona. Popija kawę. Para nie patrzy się na siebie. Sandra zmartwiona spogląda przez okno.

(III) Z piętra schodzi David ubrany w jeansy i koszulkę. Sandra przygląda mu się.

(IV) Sandra bawi się nerwowo kieliszkiem. Małżonkowie uśmiechają się_smutno. Sandra wykonuje nerwowe gesty. David popija wino wyraźnie zdenerwowany. Ucieka wzrokiem. Sandra wyczekująco wpatruje się w męża. Patrzy na mężczyznę zdziwiona.

(V) Z prawej strony kadru wyłania się Sandra. Zbliża się do kamery i spogląda w bok. Zdaje się nieobecna i pogrạżona w myślach.

(VI) Zmiana scenerii. Sandra przegląda się w lustrze lekko uśmiechnięta. Zagarnia sobie włosy za ucho.

(VII) Zmiana scenerii. Sandra i Ismail siedzą w kawiarence. Są radośni. Ismail przytakuje. Na twarzy kobiety maluje się wdzięczność. Od Ismaila bije spokój i opanowanie.

(VIII) Sandra patrzy w jeden punkt. Wiatr rozwiewa jej włosy. W oddali rozmazane światła miasta. Zbliżenie na twarz kobiety. Ma nieruchomy wzrok. Zamyka oczy.

Komentarze towarzyszące ocenie rozwiązań audiodeskrypcyjnych zastosowanych w całości badanego materiału audiowizualnego można podzielić na kilka kategorii, nie traktując przy tym granic tych podziałów jako ostrych i nieprzekraczalnych. Najwięcej opinii, 53\%, odnosi się do emocji postaci, ich nastroju lub uczuć. To stwierdzenia ogólne typu „powinien zostać oddany nastrój Sandry”, „brak opisu emocji, które w tej scenie są dość kluczowe”, „błędne rozpoznanie emocji”, ale i uwagi krytyczne wskazujące na potrzebę nazywania emocji wprost, jak na przykład „nie powiedziano, że na jej twarzy maluje się ból, zdenerwowanie etc.” czy „brak wzmianki o samozadowoleniu, podobaniu się sobie". Uwagi nawiązujące do niedostatków lub nieścisłości w opisie mimiki postaci lub ich gestów stanowią 14\% wszystkich komentarzy. W tej grupie znajdziemy stwierdzenia takie jak „zabrakło powiedzenia, że ucieka wzrokiem”, „rozczarowanie w posturze nieuwzględnione” czy „nie powiedziano, że uśmiecha się z coraz większym zadowoleniem”. Około jednej piątej $(21,5 \%)$ komentarzy wskazuje na brak istotnych informacji o czynnościach wykonywanych przez postaci lub o okolicznościach, w jakich rozgrywa się dana scena („brak opisu otoczenia”, „skąd się wyłania?”, „nie wspomniano, że wychodzą i o kolejności”). Krytyka doboru środków leksykalnych („odgarnia sobie (niepotrzebne sobie)”, „bardziej poirytowanie niż zdenerwowa- 
nie"10) stanowi 4\% komentarzy, zaś 8\% dotyczy opisów szczegółów realizacji obrazu („zbędne obraz przechodzi w”, „nie przechodzi płynnie; brak zaznaczenia, że obrazy są na siebie nałożone").

\section{Wnioski}

Komentarze respondentów stanowią pochwałę nazywania emocji wprost. Zdaje się to przeczyć wskazaniom typowym dla audiodeskrypcji standardowej, zalecającym możliwie jak najbardziej obiektywny opis tego, co widać na ekranie (między innymi ITC 2000, Snyder 2008, Szymańska, Strzymiński 2010). Ten postulat spełniałby na przykład opis wyglądu poszczególnych elementów twarzy, który składa się na wyraz danej emocji. Przytoczone fragmenty ścieżki $\mathrm{AD}$ zdają się realizować późniejsze zalecenia rozluźniające sztywny gorset wymogu jak największej obiektywności opisu. Zastosowane środki językowe plasują ten opis bliżej audionarracji, dając narratorowi wgląd w nastrój i odczucia postaci (Chmiel, Mazur 2014: 93). Wydaje się to zgodne z następującą opinią o audiodekrypcji autorskiej:

Zakładając, że aktorzy są, przynajmniej w pewnym stopniu, instruowani przez reżysera w zakresie tego, jakie emocje mają przekazać w danej scenie, a także sami interpretują daną postać, można sądzić, że nazwanie emocji tak, jak to się dzieje w AAD, może pomagać odbiorcom w interpretacji i odbiorze filmu (Szarkowska, Wasylczyk 2014: 53).

Deskryptorzy stosują też ciekawe frazeologizmy, co, jak się zdaje z powodzeniem, przyczynia się do korzystnego odbioru AD przez odbiorców, budując ich zaangażowanie (Vandaele 2012: 99). Znajdziemy w nich także elementy nurtu audiodeskrypcji odzwierciedlającej język filmu (Fryer, Freeman 2013), choć zaowocowało to kilkoma negatywnym komentarzami respondentów. W połączeniu z subiektywnymi opisami postaci zbliża je to do charakterystyki AD kreatywnej (Walczak, Feryer 2017). Autorzy AD dobrali przy tym rozwiązania zachowawcze $\mathrm{w}$ aspekcie zastosowania kreatywnych środków językowych, takich jak choćby nieoczywiste metafory. Wydaje się zatem, że studenci uczestniczący w projekcie będącym przyczynkiem do opisanego badania wypracowali własny styl opisu, czerpiący z kilku współczesnych trendów audiodeskrypcyjnych.

${ }^{10}$ Tę uwagę można interpretować także jako wskazującą na błędne rozpoznanie emocji. 
Wieloaspektowa ocena scenariusza AD przez widzących respondentów niewykształconych w zakresie tworzenia $\mathrm{AD}$ może stanowić interesujące źródło informacji o preferencjach tej części jej odbiorców, którzy mogą współuczestniczyć w wydarzeniach społecznych z jej wykorzystaniem jako towarzysze osób $\mathrm{z}$ dysfunkcjami wzroku oraz jako potencjalni adepci tej formy przekładu. Do ograniczeń przedstawionej analizy należy niezastosowanie pozalingwistycznych metod badawczych i stosunkowo skromny zakres materiału audiowizualnego poddanego omówieniu. W dalszych badaniach z pewnością warto zestawić wyniki analizy wieloaspektowej z opiniami odbiorców niewidzących w oparciu o obszerniejszy materiał referencyjny. Ciekawym rezultatem mogłoby być wypracowanie wskazówek dotyczących warunków, w jakich dana koncepcja AD ma szansę przynieść największą korzyść z punktu widzenia docelowego odbiorcy. Zasadne wydaje się przy tym zweryfikowanie relacji pomiędzy intensywnością opisywanej emocji wynikającą z gestów a informacjami na jej temat płynącymi z dialogów i ścieżki dźwiękowej. Jak zilustrowano w badaniu, można przy tym założyć że im silniejsza emocja, tym bardziej jednoznaczna jej interpretacja i tym mniejsza potrzeba wyrażenia jej explicite w audiodeskrypcji. I odwrotnie, im bardziej niejednoznaczna emocja, tym większe oczekiwanie, że potwierdzenie swoich przypuszczeń co do jej natury odbiorca znajdzie w scenariuszu AD.

\section{Literatura}

Bolińska M., 2014, Z obrazu na słowo. Kilka uwag o technice audiodeskrypcji, „Studia Socialia Cracoviensia”, 10(1), s. 169-170.

Brooks J. A., Shablack H., Gendron M., Satpute A. B., Parrish M. H., Lindquist K. A., 2017, The role of language in the experience and perception of emotion. Neuroimaging meta-analysis, „Social Cognitive and Affective Neuroscience", 12(2), s. 169-183.

Chmiel A., Mazur I., 2011, Audiodeskrypcja jako intersemiotyczny przekład audiowizualny - percepcja produktu i ocena jakości, [w:] Przekład jako produkt i kontekst jego odbioru, I. Kasperska, A. Żuchelkowska (red.), Poznań, s. 13-30.

Chmiel A., Mazur I., 2014, Audiodeskrypcja, Poznań.

Fryer L., Freeman J., 2013, Cinematic language and the description of film. Keeping AD users in the frame, „Perspectives. Studies in Translatology”, 21(3), s. 1-15.

Goleman D., 1997, Inteligencja emocjonalna, tłum. A. Jankowski, Poznań. 
Gorszczyńska P., 2016a, Tutoring: refleksja nad doświadczeniem, [w:] W trosce o jakość w ilości - program interdyscyplinarnego wspierania studenta filologii obcej w oparciu o metodę tutoringu akademickiego w Uniwersytecie Gdańskim (Ideal Quality in Good Quantity), B. Karpińska-Musiał (red.), Kraków, s. 113-125.

Gorszczyńska P., 2016b, Project management in teaching translation, [w:] Pod pretekstem słów. Księga jubileuszowa dla Profesora Wojciecha Kubińskiego, P. Gorszczyńska, W. Karwacka (red.), Gdańsk, s. 435-450.

Gorszczyńska P., Jendza J., 2016, The troubadours of knowledge and development for contextualised university studies, „Beyond Philology. An International Journal of Linguistics, Literary Studies and English Language Teaching", 13, s. 381-389.

Gorszczyńska P., w druku, Audiodeskrypcja po studencku.

ITC: ITC Guidance on standards for audio description, 2000, http://audiodescription.co.uk/uploads/general/itcguide_sds_audio_desc_word3.pdf (dostęp: 9.08.2020).

Jakobson R., 2009, O językoznawczych aspektach przekładu, tłum. L. Pszczółkowska, [w:] Współczesne teorie przekładu. Antologia, P. Bukowski, M. Heydel (red.), Kraków, s. 43-49.

Jiménez C., Seibel C., 2012, Multisemiotic and mutlimodal corpus analysis in audio description: TRACCE, [w:] Media for All 3. Audiovisual translation and media accessibility at the crossroads, A. Remael, P. Orero, M. Carroll (red.), Amsterdam, s. 409-425.

Marzec-Remieszewski M., 2017, Czy rzeczywiście znamy obszary mózgu odpowiedzialne za semantyczną analizę słów?, http://neuropsychologia. org/czy-rzeczywi\%C5\%9Bcie-znamy-obszary-m\%C3\%B3zgu-odpowie dzialne-za-semantyczn\%C4\%85-analiz\%C4\%99-s\%C5\%82\%C3\%B3w (dostęp: 8.03.2020).

Mazur I., 2014, Gestures and facial expressions in audio description, [w:] Audio description. New perspectives illustrated, A. Maszerowska, A. Matamala, P. Orero (red.), Amsterdam, s. 179-198.

Ofcom: Office of Communications, 2017, Ofcom's code on television access services, http://stakeholders.ofcom.org.uk/broadcasting/broadcastcodes/tv-access-services> (dostęp: 15.04.2020).

Orero P., 2007, Sampling audio description in Europe, [w:] Media for All. Subtitling for the Deaf, audio aescription and sign language, J. Díaz-Cintas, P. Orero, A. Remael (red.), Amsterdam, s. 111-125.

Orero-Clavero M. P., 2012, Audio description behaviour. Universals, regularities and guidelines, „International Journal of Humanities and Social Science", 17(2), s. 195-202. 
Remael A., Vercauteren G., 2007, Audio describing the exposition phase of films. Teaching students what to choose, „Trans. Revista de Traductologia", 9, s. 73-94.

Ramos Caro M., 2015, The emotional experience of films. Does audio description make a difference?, „The Translator”, 21(1), s. 68-94.

Snyder, J., 2008, Audio description. The visual made verbal, [w:] The didactics of audiovisual translation, J. Díaz-Cintas (red.), Amsterdam, s. 191-198.

Szarkowska A., 2009, Przekład audiowizualny w Polsce - perspektywy i wyzwania, „Przekładaniec”, 20: O przekładzie audiowizualnym, s. 8-25.

Szarkowska A., Wasylczyk P., 2014, Audiodeskrypcja autorska, „Przekładaniec", 28, s. 48-62.

Szymańska B., Strzymiński T., 2010, Standardy tworzenia audiodeskrypcji do produkcji audiowizualnych, Białystok, http://www.audiodeskrypcja.org. $\mathrm{pl} /$ index.php/standardy-tworzenia-audiodeskrypcji/do-produkcji-audiowizualnych (dostęp: 13.11.2019).

Tryuk M., 2008, Co to jest tłumaczenie audiowizualne?, „Przekładaniec”, 20: O przekładzie audiowizualnym, s. 26-39.

Vandaele J., 2012, What meets the eye. Cognitive narratology for audio description, „Perspectives. Studies in Translatology”, 20(1), s. 87-102.

Walczak A., Fryer L., 2017, Creative description. The impact of audio description style on presence in visually impaired audiences, „British Journal of Visual Impairment", 35(1), s. 6-17.

\section{Emotional audio description}

\section{Summary}

The article aims to summarize the results of a study that pertained to a student-authored audio description of an episode of a British TV drama entitled True Love. The material was audio described for the purposes of one of a series of film shows hosted by the University of Gdańsk and offered to Blind or Visually Impaired (BVI) audiences and their sighted fellow viewers. 25 non-AD-trained translation studies students participated in the study. They were exposed to two consecutive screenings (first of the original material, then of the $\mathrm{AD}$-enriched one) after which they were asked to fill out a questionnaire whose goal was to gain insight into their preferences concerning audio description of emotions in the reference material as well as to their own interpretation of emotions in nine scenes of the said episode. Goleman's tentative classification of emotions was used as a benchmark. Additionally, a short linguistic analysis was performed to enable mapping the describers' choices onto current $\mathrm{AD}$ concepts in an attempt at finding an optimal approach to describing emotions. It appears that 
the viewers appreciated a more direct description, involving the name of a given emotion rather than a dry description of the character's facial expression. This is especially true in the cases in which a high variation was spotted in the respondents' choices of lexical items describing a given emotion. It is, therefore, the more creative approaches to $\mathrm{AD}$ applied by the amateur audio describers that matched their expectations. These approaches, however, proved to have stirred away from the most liberal AD concepts, with no bold metaphors used in the script. Finally, directions and methods of further research into audio describing emotions were suggested.

Keywords: audio description (AD), emotions in $\mathrm{AD}$, current $\mathrm{AD}$ concepts, viewers' reception, semantic analysis, classification of emotions, BVI 